\title{
Modeling Small State Diplomacy in East Asia: How ASEAN Simulations can Help Students Understand Regional Dynamics
}

Xiaoye She, California State University San Marcos, xshe@,csusm.edu

\section{Abstract}

Do small states matter in regional politics? American students often come to an East Asian Politics class with preconceptions about regional dynamics through "national interest" lens, and less genuine interests in smaller states. To challenge these preconceptions, I introduce ASEAN simulations to help students see regional dynamics through the lens of smaller states in the region. Students first establish information literacy on competing theories and country cases earlier in the semester through assigned readings and country presentations. Then they assume the role of country delegates in a series of ASEAN simulations on regional hot topics such as nuclear proliferation, territorial disputes, and humanitarian crisis. By creating an active and collaborative learning environment, students can develop in-depth understanding of how small states pursue foreign policy objectives and seek status collectively, while critically evaluating the role of great powers in the region.

\section{Keywords}

Simulation; Southeast Asia; ASEAN; Asia-Pacific; Pedagogy; Active Learning; TLC2020; Simulations and Games 


\section{Introduction}

Do small states matter in regional politics? While scholars studying international relations and regional politics have made the case that smaller states can tell as much about the wider political world as great powers, the politicians, the mass media and the general public are naturally drawn to great powers and larger emerging economies. American students often come to an East Asian Politics class with preconceptions about regional dynamics through "national interest" lens, and less genuine interests in smaller states. In contrast to Northeast Asia, Southeast Asia contains no major power yet has the origin of most Asian regional organizations (Simon 2014). Nonetheless, the rise of multilateralism in East Asia builds upon institutions and structures of the Association of Southeast Asian Nations (ASEAN) and extends to the Northeast Asia, rather than the reverse.

To challenge common misperception from students that Southeast Asia is not relevant either at regional or global level, I introduce ASEAN simulations to help students see regional dynamics through the lens of smaller states in the region. While the literature on simulating international relations theory is bourgeoning, the literature on teaching regional politics through simulations and games is relatively small. Furthermore, simulating small state diplomacy require not only familiarity with distinctive strategies of small states but also in-depth knowledge of individual countries. Instead of throwing students into the simulations right away, we need to first take steps to help students establish knowledge competency in domestic politics of each country as well as the institutions and structures through which these small states practice diplomacy. This study therefore contributes to the simulation literature in political science and international relations by offering a step-by-step approach through which simulations and case studies are integral part of a semester-long studentcentered learning experience.

In the East Asian Politics class, students first establish knowledge competency on competing theories and country cases earlier in the semester through assigned readings, country presentations 
and news briefing exercises. Then they assume the role of country delegates in a series of ASEAN simulations on regional hot topics such as nuclear proliferation, territorial disputes, economic integration, and humanitarian crisis. After the simulation exercises, it is also critical to ask students to reflect on their collective learning experience, and examine any advance in their knowledge and personal growth. These can be done through peer evaluations, self-reflections, and formal written assignments such as foreign policy papers. By creating an active and collaborative learning environment, students can develop in-depth understanding of how small states pursue foreign policy objectives and seek status collectively. They were able to develop compassion and empathy for smaller states and historically marginalized groups within these states, and critically evaluating their own preconceptions and the role of great powers in the region. Once they complete the simulations, students are asked to extract from their country roles and complete a foreign policy paper with more deeper understanding of regional politics.

\section{Simulations and Active Learning in International and Regional Politics}

International relations as a field has long traditions for simulations and games for both practitioners and educational audiences (Starkey and Blake 2001). Ellington, Gordon and Fowlie (1998:2-3) define simulations as "ongoing representations of real situations", games are being made up of "competition and rules", and cases as "in-depth studies carried out to illustrate special characteristics". Most importantly, they are not mutually exclusive and teachers can integrate elements of more than one type to help students deepen their understanding of relevant political science concepts and theories (Ellington et al 1998; Asal 2005). McCarthy (2014) also highlights the roles of games and simulations in teaching abstract concepts such as anarchy, cooperation and conflict at international system level.

On the other hand, simulations have been less used in an upper-division comparative regional politics class. For regional politics, case studies of individual countries or their comparisons are most 
important pedagogy tools in the classroom. Outside of the classroom, most simulation programs for non-practioners are largely adaptations of the Model United Nation program, such as Model Organization of African Unity (OAU), Model European Union, and Model ASEAN. While such simulations facilitate student learnings within these geographic regions, it is logistically less feasible and costly for students outside these regions to participate in these out-of-class simulation programs. Therefore, faculties at various universities and colleges have developed smaller scale simulations both across campuses and within specific classrooms (Starkey and Blake 2001). For example, University of Maryland's ICONS project includes several role-play simulations on regional politics including Baltic Security Crisis, European Union, Africa, and Southeast Asia. Students or the instructor need to pay for participating similar to a lab fee or supplemental text fee. Others such as Council on Foreign Relations (CFR) developed the free-of-cost Model Diplomacy program, which includes National Security Council (NSC) and United Nations Security Council (UNSC) simulations that explore regional topics.

While the usage of simulation in the teaching of regional politics is growing, there have been few attempts to integrate such practices into the broader pedagogy literature of international relations. When such practices are discussed, they often focus on formalized, iterated simulations outside of the classroom. Raymond and Sorensen (2008) for example discussed the use of a Middle East Crisis simulation in a Model United Nations Club (MUN). As Wakelee (2008: 70) points out, sometimes it is not feasible to spend substantial course time conducting elaborately constructed, in-depth simulations. Online simulation platforms like ICONS and Model Diplomacy require instructors and the students to spend significant time getting familiar with the online structure. While such learning process can be valuable for a broader international relations or global governance class, it will be particularly challenging and time costly for regional politics class, where students need to also develop in-depth knowledge of individual countries as well. Rather than diving into the specific issue, in-class, 
shorter duration simulations can help highlight particular point or concept, strengthen retention of material, and help students take ownership of the materials (Wheeler 2006, p.155; Wakelee 2008, p. 72).

Drawing on Petranek (2000) and Asal and Blake (2006), I suggest that students of regional politics can benefit from simple, one- or two-session simulations designed by the instructor that requires no financial commitments or prior knowledge of online platforms. The biggest challenge of short duration simulations is how to help students quickly immerse themselves into the experience, and how students can grasp key ideas in such short time. In this regard, instructors can consider borrowed the idea of "immersive theater" as discussed by Dacombe and Morrow (2017) and adapt the classroom to mimic the simulated environment. In addition, rather than treating simulations as stand-alone exercises, the instructors can integrate iterated simulations into a semester-long active learning sequence, and incorporate other active learning pedagogy tools such as pre-simulation case studies of individual countries and regional news briefings, and debriefing exercises such as peer evaluations, self reflections, and formal written assignments such as foreign policy papers.

Creating a positive team-based learning environment prior to simulations is critical to a successful simulation experience. Through early-on interactions in the case studies stage, students not only develop common knowledge and understanding of the countries they represent, but also learn to effectively communicate with their teammates and build trust. Following the simulation, students are asked to complete a series of peer evaluations, personal reflections, and a written foreign policy paper. These debriefing exercises help students to deconstruct and critically reflect on their learning experience and develop more informed understanding and analysis of regional issues. 


\section{Why ASEAN Simulations for East Asian Politics?}

There are no clearly defined boundaries for East Asia (Shambaugh 2014). In this paper, East Asia is defined as Northeast Asia (includes the two Koreas, Japan, China, Taiwan, and Mongolia) and Southeast Asia (includes the ten ASEAN states). Political and economic relations in the region has been marked by complexity and volatility in the twentieth century. While the region as a whole has experienced remarkable economic growth, greater economic interdependence and geographical contiguity do not guarantee political unity. Tensions often rise, and efforts to regionalism are often overshadowed by historical legacies, diverse national contexts, as well as regional and external great power rivalries.

Traditionally, more scholarly attention in international relations has been paid to Northeast Asia while more vibrant research on Southeast Asia focus come from area studies or comparative politics. In international relations, there are constant debates about whether ASEAN is important or relevant as a regional organization (Acharya 1992; Kraft 2000; Heller 2005; He 2006; Egberink 2010). The dearth of coverage on this regional organization in western mass media contributes to students' lack of knowledge of the region in general and the regional organization in particular. And when it is mentioned, it is often described as a dysfunctional entity or a talk shop (Acharya 2009). It is thus not surprising that students demonstrate lack of interest at the beginning of class but prefer to focus more on the Northeast Asia.

However, there are main two reasons why studying and simulating ASEAN can contribute to our understanding of regional dynamics in East Asia and more broadly international relations. First, ASEAN is among one of the regional organizations that is formed out of recently independent countries, with a diversity of political regime types and mostly ethnically and linguistically diverse countries. Because of the historical contexts, the rule-making structure at ASEAN is significantly different from regional organizations in western context or even other developing regions such as 
Latin America and Africa. Consensus building and conflict resolution are primary objectives for multilateralism, rather than establishing supranational authority that potentially challenges sovereignty. Non-interference on domestic affairs has been one of the founding principles since ASEAN was formed. More importantly, concerns for over-expansive multilateralism or supranational authority seems to be shared by ASEAN's Northeast neighbors, who would prefer to rely on ASEAN to discuss important security and economics issues rather than creating stand-alone formal regional institutions themselves.

The second reason has to do with great power rivalry and small state diplomacy, two important subjects in the study of East Asian politics and international relations broadly. Egberink and Putten (2010) for example argue that although ASEAN's influence may be limited, studying ASEAN and how it deals with increasing geographic rivalries is highly relevant to our understanding of geopolitical stability in both East and South Asia. While the class scope is limited to East Asia, India at times can be brought up as a background factor just like China or United States in the ASEAN simulations. Furthermore, rather than seeing ASEAN as an actor itself, it is more conducive to see ASEAN as an arena or forum where sovereign states that are traditionally considered small or weak individually or collectively seek to amplify their voices and exert greater influence. Henrikson (1999; 2001) for example identifies several types of diplomacy associated with multilateralism, such as group diplomacy, multicultural diplomacy, regulatory diplomacy, and summit diplomacy. Singapore, one of the founding ASEAN members and a small city-state, for instance, is known for its usage of such strategies.

Designing a course structure that incorporates both Northeast Asia and Southeast Asia and explores ASEAN as the building block for regionalism therefore help students develop a more comprehensive understanding of regional dynamics. On the first day of class, I complete a baseline assessment that asks students to examine their preconceptions about East Asia and expectations for the class. After reading the syllabus, there will always be students asking, "why do we need to study 
Southeast Asia", or "I just want to learn about China, Korea, and Japan"? Rather than lecturing students about the importance of Southeast Asia, I create a series of group-based activities that gradually allow students to "immerse" themselves into the Southeast Asia region and specific countries. Students will sign up for the group-based activities at the beginning of the semester. The idea is to build a shared understanding of smaller countries that are traditionally considered "less important" in the region, before simulating their interactions with great powers and other small states on contentious regional issues. Every student will have the opportunity to become country experts as a group. Student groups will prepare an oral presentation on the country assigned, a news briefing assignment on both Northeast and Southeast Asia, and lead class discussions on domestic politics, foreign policy current events.

After all country presentations are complete, we will run the ASEAN simulations. The goal is to explore how small states in the region conduct diplomacy to pursue their foreign policy objectives and seek status collectively. Students also learn about how political institutions and culture as well as great power politics shape the working of the regional community. Building on their country expertise, students play the role of country representatives at the ASEAN summit, the ASEAN Political-Security Community, the ASEAN Economic Community, or the ASEAN Socio-Cultural Community. depending on the issue topic. Each country team will be responsible for preparing draft statements and briefing other countries about your country's positions on specific issues at the beginning of the simulation. Students will then participate in formal and informal meetings with the goal of reaching consensus and issuing joint statements on the issues at stake. All group activities in this class will be peer evaluated and the results are factored into student grades.

\section{Becoming Country Experts through Case Studies and News Briefing}

The first step is to help students in the class establish common knowledge of small states in the region and prepare them for the ASEAN simulation experience. This is done through group 
preparations about the countries of their choice, and a weekly news briefing exercise that covers key issues occurring in the region of Southeast Asia. With a combination of recommended readings and online resources, students are asked to take ownership of the materials, and educate the whole class about the assigned country from historical, theoretical and policy perspectives. The following broad questions are provided to guide their research and presentation processes:

1. How does the country/case relate to the readings/topics of the class?

2. Can you use comparative politics and international relations theories to explain key historical and current events in the country?

3. What are the most current issues and challenges faced by this country? Why should we care and learn about these issues?

4. What are the key issues that leaders in the country are most concerned about? How about people in that country?

5. From a U.S. foreign policy perspective, how would you describe the current bilateral relations? How would you predict things moving forward?

In addition, students are asked to cover the following themes and provide 1-3 slides per issue topic:

1. Why study this country

2. Geographic and demographic features

3. State formation

4. Political regime(s) and regime transition

5. Political competition and conflict

6. State-society relations 


\section{Political economy}

8. Foreign policy and international relations

\section{Current issues}

10. U.S. foreign policy on the country: current strategies and suggestions

Some academic journal articles and online resources are provided to help students prepare for the simulation. Articles are selected from regional studies journals such as Journal of Asian Studies and Contemporary Southeast Asia. For news briefing, students are recommended to use news sources outside of the United States to extract themselves from a "national interest" and provide them alternative views about the region. Potential outlets include BBC News Asia, South China Morning Post from Hong Kong, Asahi Shimbun from Japan, Chosun Ilbo from South Korea, Taipei Times from Taiwan, and Strait Times from Singapore. In addition, students are directed to various online resources such as ASEAN website, the Asian Society, CIA World Factbook, BBC Country Profiles, Library of Congress, and Council on Foreign Relations.

When preparing in groups, students were given time in class to come up with a research plan, through which they establish most effective ways of communication, divide labor among themselves on the guiding questions and themes, set meeting times, and assign logistical tasks such as setting up the master slides and final checks to make sure there is no misspelling, grammar mistakes or duplications and redundancies. It is critical to allow some in-class time for the groups to start working together, so they can form the habit of constant communication and collaboration that can sustain through the country presentations, news briefings, and later the ASEAN simulations. Once students complete their preparation, they will be asked to brief the class major regional news of that week, present the country, and then lead class discussion by turns. Every group member will bring three unique discussion questions which they cross-check before class. The questions should be analytical, 
theoretical/empirical, and relevant to class readings and topics. Following the presentation and discussion, students will complete peer evaluation and audience surveys which will be incorporated into overall grades.

\section{Preparing for the Simulations}

Students need to be informed about why we are doing simulations and how they can prepare for them. While the gaming logic behind simulation can be exciting for students, there are always some who would ask the question "why not just lectures"? Simulations as well as other active-learning pedagogy tools can take significant amount of class time. For students who prepare traditional teaching methods, they may not enjoy and benefit educationally unless they are fully briefed about the purpose and how to prepare (Torney-Purta 1998, p. 95). This can be done by briefing students earlier in the semester and provide student learning objectives for the simulation in class handouts. For this class, I provided students three broad learning objectives: first, to help students understand how ASEAN function as a regional intergovernmental organization; second, to help students explore how small states in the region conduct diplomacy to pursue their foreign policy objectives and seek status collectively; and third, to learn how domestic politics and great power dynamics in the region shape the working of the regional community. The following description was also provided in regard to simulation preparation: "Building on your country expertise, you will assume the role of foreign diplomats and policy experts in that country, conduct research on your country's policies and/or priorities on the particular issue assigned during that week, and prepare draft position statements."

Before the simulation begins, it is essential to provide students a baseline understanding of how ASEAN works and their country's position and power within the organization. Background materials on ASEAN are handed out during class sessions. In particular, the role of the original "ASEAN Five" on the eastern part of the region are highlighted as well as those with stronger economic standing such as Singapore, Brunei, and to a less extent Malaysia. After reading the materials, 
students come back to complete a quiz on the background material, where they demonstrate their knowledge competency on the historical trajectories and current institutional structure of the regional organization. Students also complete a reflection exercise on ASEAN's mission statement and anthem "The ASEAN Way" and analyze its meanings.

On the online learning system, I create simulation folders for each simulation topic, such as the North Korea nuclear proliferation, the South China Sea maritime disputes, the Regional Comprehensive Economic Partnership (RCEP), and the Rohingya Crisis in Myanmar. While some scholars have discussed the usage of hypothesized scenarios such as a zombie academic in simulating world politics (Michelsen 2010; Horn et al 2016; Fischer 2019), students of regional politics can be more informed in their choices if they are placed in real world scenario, have access to positions and stances of various countries involved, and therefore make more informed decisions when drafting statements and responding to other student groups. Although these topics are pre-selected, the list of simulation topics can be easily expanded to cover other "hot topics" of the region such as China's development finance and Indonesia’s natural disasters and environmental issues.

Across all topics selected, only one or two will be exclusively focusing on the region itself. Other simulation topics will involve multiple great powers or bigger neighbors, such as China, United States, Japan, and the Koreas. Still, these great powers are considered as background factors in these simulations. The goal is to form consensus and resolve conflicting positions of ASEAN members, rather than addressing the more complex question of negotiating and bargaining with outsiders. Since ASEAN is one country, one vote, student groups are therefore in relatively symmetric power positions, therefore allowing them to concentrate on the simulation experience rather than being distracted by power dynamics. 
Before each simulation starts, students will work in groups to explore the online simulation folders and conduct research for their country's position. Each "country delegation" will draft a twopage, single-spaced position statement and bring it to class. The importance of having some kind of briefing notes was highlighted by Druliolle (2017). In this class, I asked students to provide a formal written position statement where they learn to draft their country's positions using diplomatic language collectively. Students have demonstrated improved usage of diplomatic language over time through iterated practices.

The position statements contain some, if not all, of the following elements:

1. How the issue affects the country

2. Current country policies with respect to the issue and justification for these policies

3. Quotes from country's leaders about the issue

4. Statistics to back up country's position on the issue

5. Conventions and resolutions that the country has signed or ratified

6. Actions that the country supported or opposed so far

7. What further action the country believes should be taken to address the issue

8. What the country would like to accomplish in the respective meetings

9. Anticipations about other countries' positions and responses to those positions

While students are not discouraged to bring up personal perspectives on the issue, they are reminded that these position statements are not their personal statements, but rather perspectives of the government/political regime in power from the individual countries they are representing. Sometimes students may find their own views in clash with the views of national governments in that particular country and find themselves out of their comfort zone. It is important to remind students 
that having emotions in the process is normal, but also encourage them to hold their emotions until the debriefing part of the class. I also made clear early on that students will have the opportunity to extract their roles, complete simulations reflections and write an individually-based foreign policy paper on the issue of their interest.

\section{Simulation in Action}

To allow students quickly immerse themselves into the simulations, I created a 5-minute opening ceremony for each simulation where rotating country representatives join the stage to hold hands and take pictures with the "ASEAN Way" anthem in the background. With student permissions, I take pictures of the opening ceremony and post them on the online class community site. In addition, we also rearrange seats in the classroom to mimic the setting in an actual ASEAN Summit or Community meeting. The county representatives will sit in a circle, while the rest of the delegation will sit behind the representative. During formal meetings, this allows the representatives to turn back at times to consult with their delegation members. With all seats are now in the middle of the class, the outer areas are marked as "lobby areas" where country delegations can negotiate and exchange ideas during adjournment sessions. This resembles the "immerse theater" approach as discussed by Dacombe and Morrow (2017) and help students immerse into the simulations more quickly.

The end game of each simulation is to adopt a consensus statement, which can be a binding agreement or a symbolic statement. During the simulation, the ASEAN chairperson will circulate background information, ask country delegates to present their positions, take notes, and synthesize agreed upon points to form a draft consensus document. The first formal meeting will begin with the chairperson making an opening statement about the issue. Then chairperson will then give each delegate a few minutes to present their position statement, before opening up for floor discussions. There is no fixed speaking order, but the chairperson must acknowledge the country prior to their delegate speaking. Such formal meetings can be divided into several rounds, with adjournment or 
informal meetings in between that allow country delegates to walk around and exchange ideas privately. Such adjournment can be requested by country delegates if they wish to negotiate with another country. Before adjournment, the chairperson may ask all countries to come to agreement about how long the adjournment will take. Country delegates may come back from an adjournment making new proposals that are agreed upon after behind-the-door negotiations. The chairman will circulate the draft statements and incorporate feedback from all member states, before calling for a vote on the proposed clause.

The defining character of the ASEAN way, or the primary mode of decision-making at ASEAN are consultation and consensus, which is viewed as a philosophical and cultural tradition in the region. It ensures only the initiatives with full support can be passed and no member states will feel excluded or disadvantaged. This one-country, one-vote system speaks to sovereignty, selfdetermination and ideally equal representation in a regional that shares traumas of colonialism and imperialism, conflict, and uneven development. This system however comes with some significant pitfalls. With de facto veto power of every member state, students may frequently find them in deadlock situations. It is useful in this regard, to give early tips to country delegations to help them become deal brokers. Tools of diplomacy such as positive or negative sanctions, compellance and deterrence may be used in negotiating deals. Frustrations can easily happen when negotiations fail or uncertainties arise, but it is also a lesson for real world scenarios. And students will find out that in most days, there is less likely to be a collective action, but more likely to have a vague, symbolic statement with no binding authority. As Sasley (2010) points out, students can also benefit from learning about possibility of failure through simulations.

The first day of simulation can be an overwhelming experience for students. Students who have no simulation experience before may be nervous, do not know what to do, and may choose to be completely silent other than reading the position statement out. There are two strategies to address 
this. First, the instructor should always chair the first simulation meeting and facilitate discussion and debates. Once students feel more comfortable, the instructor may ask volunteers to take on the role of ASEAN chairman. In this regard, the instructor can set an example on the first day through more active intervention, than extract to an observatory role in later simulations. Second, the instructor can create a mock simulation exercise that is not graded. In my other lower-division international relations class, I adapted on online simulation from United Nations Association (UNA) to develop an in-class United National Security Council (UNSC) simulation on international zombie epidemic, before we move on to real world issues such as nuclear proliferation, Venezuela's crisis, and humanitarian intervention in Sudan. While I have not applied this strategy to the ASEAN simulation, I plan to test this strategy for future classes.

\section{Simulation Debriefing and Reflections}

Debriefing is critically to simulation success as it helps students make sense of the experience and how it relates to the class. In addition, good debriefing can contribute to positive learning where students can avoid mistakes and improve their strategies in future iterations. After each ASEAN simulation, students will first be given time to orally debrief the simulation exercise. Questions that are discussed include:

1. What were the simulation results? Do they meet your expectations? Why or why not?

2. Which comparative politics and/or international relations theory best explains the simulation outcome?

3. Which level of analysis (international system, state or individual) best explains the simulation outcome?

4. Was your country delegates in character? How about everyone else?

5. How do you feel during the simulations? Describe your emotions. 
6. Is there anything we can improve for the next simulation?

7. If this is the last simulation, what will be your ONE suggestion to students next year?

Students are also asked to complete peer evaluations on their group performance. In the peer evaluation, students are asked to assign scores that reflect how they really feel about the extent to which other group members contribute to their learning, and the overall group performance in the simulations. Students are also reminded that this is their opportunity to reward teammates who worked hard on their behalf, and that their feedback matters for both grading purpose and personal growth. When distributing the points, students are asked to assign an average of 10 points to other members of their group. For example, a total of 20 points are assigned to a 3-member team, or 30 points to a 4-member team. Students can differentiate their ratings with multiple contributors. For example, they may assign 12 points for teammate $\mathrm{A}$, and 8 points for teammate $\mathrm{B}$. The maximum score they can give a particular teammate is 15 . In the comment column, students are asked to briefly describe their reasons for their ratings. These comments, but not information about who provided them, will be used to provide feedback to students who would like to receive it.

Along with peer evaluation, students are asked to complete a self-reflection based on the simulation exercise. The following questions are asked for the self-reflection:

1. What are your main takeaways from the simulation? What did you learn about regional politics and small states?

2. What do you think of the simulation format? What do you like most? Any suggestions to improve the simulation design/structure?

3. On the scale of $0-10$, how would you assess your own contributions and performance for the simulation exercise? 
4. What could you have done/What can you do in the future to improve your contribution and performance?

5. What can the instructor do to help you improve your contribution and performance?

\section{Assessing Student Learning Outcomes}

Kollars and Rosen (2013) discussed how simulations can be used as active assessment themselves. In particular, they highlighted how certain types of simulations require students to justify their actions based on theories and key concepts, and therefore replace tests and exams as assessment tools. In the East Asian Politics class, the sequence of active learning components from case studies and news briefing to simulations and final paper provide the instructor step-by-step opportunities to assess student learning outcomes. During the case studies and simulations, students are assessed by their marked contributions to the group written assignments and their in-class performance when leading discussions. For each, I developed a four-point rubric for understanding of the issue and inclass performance. For understanding of the country or issue, students who are considered as "exceeds" can receive full four points if they demonstrate sophisticated understanding of the issues, events and facts related to the topic, and are able to make their own connections and interpretations. For oral performance, students who receive four points typically exhibit outstanding confidence and passion, maintain respectful tones, consistently maintain eye contacts, use visuals effectively (if used), and use language that is stylistically sophisticated and appropriate for a college course.

Towards the end of the semester, students are asked to extract from their roles as country representatives, and reconsider one key issue in the simulations from a U.S foreign policy perspective. It is critical that this written assignment takes place after all the previous steps, including the case studies and simulations. When weighing policy options, students can now take into consideration factors such as: 1) history, culture, politics and economy of the region; 2) historical roles of the United 
States and changing U.S. foreign policy priorities in the region; 3) domestic politics and foreign policies of regional powers; 4) the role of small states and regional institutions such as ASEAN.

When designing their paper, students are asked the following questions:

1. Who is the decision-maker? Who is the intended audience?

2. Why is the issue urgent and why does it require the United States to take action?

3. What are the policy options? When and where should action take place?

It is critical that students know and demonstrate how they arrive at their findings or recommendations through their case studies and simulation experience. This can be done through a guided step-by-step approach for students to develop their papers and highlight possible ways for them to incorporate their insights from the case studies and simulations. Without the prior steps of case studies and simulations, students may come from a top-down perspective or ask the question "why should we care". An integrated and immersive active learning approach therefore help students develop empathy and compassion for the small states and allow them to be emotionally invested to the specific countries and issues.

\section{Conclusion}

This paper explores ways to incorporate simulations into regional politics class and make it an effective active learning tool to understand both great power rivalry and small state diplomacy in a region that was historically suspicious of multilateralism or regionalism that would undermine national sovereignty. American students often struggle to understand the relevance and importance of small states in Southeast Asia and regional organization without great powers like ASEAN. This paper discusses strategies to engage students in critical reflections of their preconceptions about these small states, ASEAN, and regional dynamics in East Asia. Although the focus is in East Asia, the strategies 
discussed in this paper have the potential to be applied to other regional politics classes that contain both comparative politics and international relations components.

Rather than introducing students to formalized simulations such as Model ASEAN or ICONS, I develop a series of small, in-class simulations that are combined with pre-simulation case studies and post-simulation written assignments. This strategy helps reduce the potential time dedication and financial cost associated with the out-of-classroom or online platforms. In addition, it allows more effective integration of the simulations into the course curriculum. To help students quickly immerse into the simulation environment during relevant class sessions, I designed an open ceremony similar to ASEAN Summit or Community meetings, and adapted the classroom environment to create a roundtable formal meeting room and lobby areas for informal negotiations. Following the simulations, students are asked to complete a series of reflective exercises including in-class oral debriefing, peer evaluation, and self-reflection. The final policy paper allows students to extract from their simulation roles and tackles the same issues from a U.S. foreign policy perspective, yet with deeper understanding of the regional context and stakeholders involved.

This paper presents a first-hand experience for developing simulations and an integrated approach with various active learning tools in a regional politics class. The simulation structure developed in this class is still in its early stage. Preliminary student data was collected last semester to improve course design and pedagogy tools discussed in this paper. Formal assessment tools are to be developed to better evaluate student learning outcomes. For instance, it may be helpful to develop a comparable, standardized pre- and post-test to capture student learning, and a more comprehensive rubric for both written assignments and in-class simulation performance. While students completed a series of quizzes on ASEAN and specific countries right before the simulations, some of the quiz questions can be extracted to form pre- and post-tests that examine whether their knowledge competency have improved after the case studies and simulation experience. To improve simulation design, there are two additional 
directions to be considered. One is to engage students more actively in the design of the simulations by asking them to help design the rules of the game during earlier part of the semester. Such strategies have been discussed by Glasgow (2014) but has not been applied to regional politics simulations. The other is to incorporate some experimental designs in the simulations in the future as discussed by Lohmann (2019), and help students discuss alternative issue scenarios and how they can respond under each circumstance. 


\section{Bibliography}

Acharya, A., 2009. Arguing about ASEAN: what do we disagree about? Cambridge Review of International Affairs 22, 493-499. https:// doi.org/10.1080/09557570903138444

Acharya, A., 1992. Regional military-security cooperation in the Third World: A conceptual analysis of the relevance and limitations of ASEAN (Association of Southeast Asian Nations). Journal of Peace Research 29, $7-21$.

Asal, V., 2005. Playing Games with International Relations. International Studies Perspectives 6, 359-373. https://doi.org/10.1111/j.1528-3577.2005.00213.x

Baldacchino, G., 2009. Thucydides or Kissinger? A Critical Review of Smaller State Diplomacy, in: Cooper, A.F., Shaw, T.M. (Eds.), The Diplomacies of Small States: Between Vulnerability and Resilience. Palgrave Macmillan UK, London, pp. 21-40. https://doi.org/10.1057/9780230246911 2

Dacombe, R., Morrow, E.A., 2017. Developing Immersive Simulations: The Potential of Theater in Teaching and Learning in Political Studies. PS: Political Science \& Politics 50, 209-213. https://doi.org/10.1017/S1049096516002456

Druliolle, V., 2017. There is No Debriefing Without Prior Briefing: Writing a Briefing Memo as a Preparatory Activity to Make the Most of the Pedagogical Potential of Simulations. Journal of Political Science Education 13, 355-363. https://doi.org/10.1080/15512169.2017.1331850

Egberink, F., Van der Putten, F.-P., 2010. ASEAN and strategic rivalry among the great powers in Asia. Journal of Current Southeast Asian Affairs 29, 131-141.

Ellington, H., Earl, S., 1998. Using games, simulations and interactive case studies: a practical guide for tertiary-level teachers. Staff and Educational Development Association.

Fischer, B.A., 2019. Fact or Fiction? Designing Stories for Active Learning Exercises. Journal of Political Science Education 15, 179-190. https://doi.org/10.1080/15512169.2018.1447947

Glasgow, S.M., 2014. Stimulating Learning by Simulating Politics: Teaching Simulation Design in the Undergraduate Context. International Studies Perspectives 15, 525-537. https://doi.org/10.1111/j.1528$\underline{3585.2012 .00501 . x}$

Handel, M.I., 2016. Weak states in the international system. Routledge.

He, K., 2006. Does ASEAN matter? International relations theories, institutional realism, and ASEAN. Asian Security 2, 189-214.

Heller, D., 2005. The relevance of the ASEAN Regional Forum (ARF) for regional security in the Asia-Pacific. Contemporary Southeast Asia: A Journal of International and Strategic Affairs 27, 123-145.

Henrikson, A.K., 2001. A coming 'Magnesian'age? Small states, the global system, and the international community. Geopolitics 6, 49-86.

Henrikson, A.K., 1999. Small states in world politics. Industry Focus 17-19.

Horn, L., Rubin, O., Schouenborg, L., 2016. Undead Pedagogy: How a Zombie Simulation Can Contribute to Teaching International Relations. International Studies Perspectives 17, 187-201. https://doi.org/10.1111/insp.12103

Ingebritsen, C., Neumann, I., Gsthl, S., 2012. Small states in international relations. University of Washington Press.

Kollars, N.A., Rosen, A.M., 2013. Simulations as Active Assessment?: Typologizing by Purpose and Source. Journal of Political Science Education 9, 144-156. https://doi.org/10.1080/15512169.2013.770983 
Kraft, H.J.S., 2000. ASEAN and intra-ASEAN relations: weathering the storm? The Pacific Review 13, 453-472.

Lohmann, R., 2019. Taking a Glimpse Into the Future by Playing? Simulation \& Gaming 50, 377-392. https://doi.org/10.1177/1046878119848133

McCarthy, M.M., 2014. The Role of Games and Simulations to Teach Abstract Concepts of Anarchy, Cooperation, and Conflict in World Politics. Journal of Political Science Education 10, 400-413. https:// doi.org/10.1080/15512169.2014.947417

Michelsen, N., Goggins, A., 2010. Teaching World Politics With Zombies. Presented at the Annual Convention of the American Political Science Association, Washington, DC, September.

Raymond, C., Sorensen, K., 2008. The Use of a Middle East Crisis Simulation in an International Relations Course. PS: Political Science \& Politics 41, 179-182. https://doi.org/10.1017/S104909650808027X

Sasley, B.E., 2010. Teaching Students How to Fail: Simulations as Tools of Explanation. International Studies Perspectives 11, 61-74. https://doi.org/10.1111/j.1528-3585.2009.00393.x

Schnurr, M.A., De Santo, E.M., Green, A.D., 2014. What do students learn from a role-play simulation of an international negotiation? Journal of Geography in Higher Education 38, 401-414. https://doi.org/10.1080/03098265.2014.933789

Shambaugh, D., 2014. International Relations in Asia: A Multidimensional Analysis, in: International Relations of Asia. Rowman \& Littlefield.

Shambaugh, D., Yahuda, M., 2014. International relations of Asia. Rowman \& Littlefield.

Simon, S.W., 2014. ASEAN and Southeast Asia: Remaining Relevant, in: International Relations of Asia. Rowman \& Littlefield.

Starkey, B.A., Blake, E.L., 2001. Simulation in International Relations Education. Simulation \& Gaming 32, 537551. https://doi.org/10.1177/104687810103200409

Taylor, K., 2013. Simulations Inside and Outside the IR Classroom: A Comparative Analysis. International Studies Perspectives 14, 134-149. https://doi.org/10.1111/j.1528-3585.2012.00477.x

Wakelee, D., Wakelee, D., 2008. Short duration political science simulations.

Weatherbee, D.E., 2014. International relations in Southeast Asia: the struggle for autonomy. Rowman \& Littlefield.

Wheeler, S.M., 2006. Role-Playing Games and Simulations for International Issues Courses. Journal of Political Science Education 2, 331-347. https://doi.org/10.1080/15512160600840814 